\title{
Recent seismicity of southern Ghana and re-interpretation of the 1939 Accra earthquake: implications for recurrence of major earthquake
}

\author{
Jacob M. Kutu*, Chris Y.Anani, Daniel K.Asiedu, Johnson Manu, Ebenezer Hayford, Isaac Oppong \\ Department of Earth Science, University of Ghana \\ *Corresponding authorE-mail: jkutu@ug.edu.gh
}

\begin{abstract}
The purpose of this research is to re-interpret the 1939 Accra Earthquake, explain the nature and cause of the recent seismicity of the Accra region, and assess the likelihood of occurrence of any major cyclic earthquake in the Accra region and southern Ghana. Combining re-interpretation of historical earthquake data of Ghana with new field data, the nature of the seismicity of the Accra region has been assessed. The results show that the 1939 Accra Earthquake was a shallow-focus tectonic event caused by high-angle submarine strike-slip faults along the eastern extension of the Romanche fracture zone 40 kilometres south of Accra. Recent seismicity in the Accra region has emanated from sources similar to those of the 1939 Accra Earthquake related to the offshore fault systems. The structural setting and mechanism of the 1939 earthquake, however, preclude the likelihood of occurrence of a major cyclic earthquake based on a regional cyclic earthquake phenomenon. The results, however, do not exclude the possibility of occurrence of any significant random earthquake striking Accra region or other parts of southern Ghana now or in the future, as there are many independent active fault systems associated with the fault systems of the region.
\end{abstract}

Keywords: Accra region, re-evaluation, Romanche transform-fault and fracture-zone system, fault splays, seismic periodicity, southern Ghana.

\section{Introduction}

Ghana and the Accra region are located far away from any present-day tectonic plate boundaries and active seismic and volcanic regions of the world. However, for centuries now, a number of significant earthquakes have struck southern Ghana, some with destructive effects, as occurred in 1636, 1862, 1906, and 1939 [1, 2, 3, 4, 5, 6]. The latest and most destructive earthquake of all these events was the 22nd June 1939 Accra Earthquake that occurred some 74 years ago [2].

Recently in the last two and half decades, several earth-tremors of magnitudes 3.8 to 4.8 have trembled the Accra region and southern Ghana $[6,7,8,9]$. These recent events have given cause for concern and speculation of the possibility of occurrence of a major earthquake in the Accra region [6, 7, 8, 9], based on the 77 years interval (1862-1939 Accra) or 74 years interval (1939-2013 Accra) suspected to be cycles. For instance, Ghana News Agency [8] reported that "the Ghana Geological Survey had warned that Accra was on the verge of experiencing an earthquake due to the frequency of seismic readings in recent times". But, clear geological explanation for the suspected large earthquake and the recent seismicity of the Accra region and southern Ghana is unavailable. The question is: "what is causing the seismicity of the Accra region that is defined by the crustal boundary faults around the Accra-Tema-Koforidua-Akosombo-Ho corridor of southern Ghana?" Is whatever causing seismicity in the region periodic?

The objectives of this paper are to re-interpret the seismic features of the 1939 Accra Earthquake, explain the nature of the earthquake phenomenon, establish cause of the recent seismicity of the Accra region and southern Ghana, and find reasons for the likelihood of occurrence or otherwise of any major cyclic earthquake in the Accra region and southern Ghana.

\section{Geological setting}

The Accra seismic region (Fig. 1) is part of the NE-SW-trending convergence tectonic closure and sutured boundary zone between the basement terranes of the Proterozoic Birimian province of the West African Craton to the west, and the Dahomeyide Orogenic terrane to the east [10]. Along this tectonic boundary, that runs inland northeastwards from 
the Gulf of Guinea through southeastern Ghana, the Republics of Togo, Burkina Faso to Mali, the Dahomeyide Orogen is thrust westward onto the eastern margin of the West African Craton. In southern Ghana, it is characterized by three boundary-parallel tectonic units. These are the rocks of the Birimian crust as the western block, the narrow middle or internal meta-sedimentary unit referred to as the Akwapimian (or Togo Formation) block, and the rocks of the granulite Dahomeyide terrane block to the east, all separated by clear lithotectonic fault boundaries (Fig. 1).

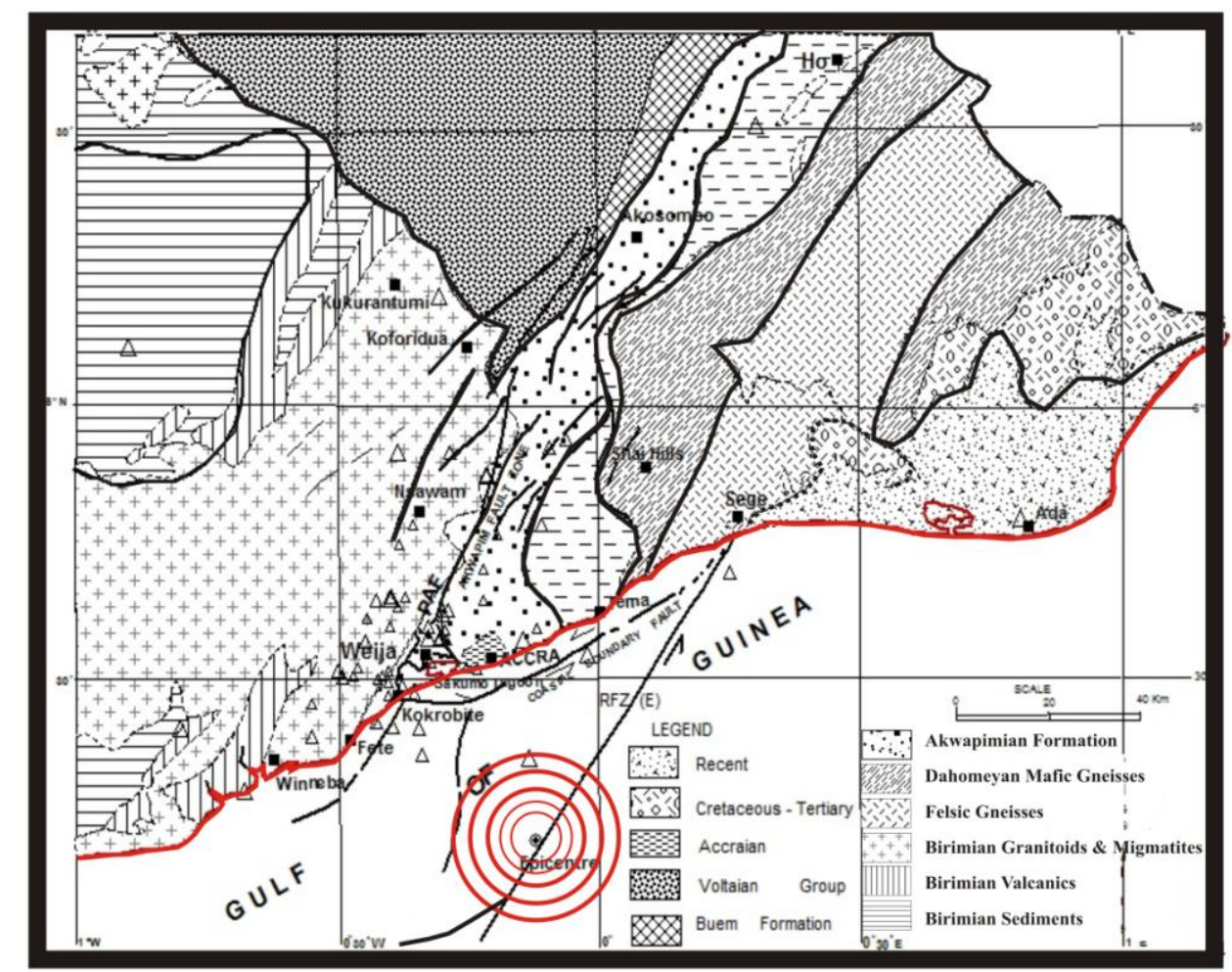

Fig. 1: Map showing southerneastern Ghana and the Accra region, Accra boundary faults, and the epicentre of the 1939 Accra Earthquake (modified after Junner et al. [2])

The Dahomeyide Orogen is subdivided into two units: the internal unit, and the adjoining external unit to the east. The internal unit is the Akwapimian block that forms the western belt of the Dahomeyide Orogen. It is a thin-skinned beltzone or middle block (apparently a detached sliver) over $800 \mathrm{~km}$ long with variable width 2 to $25 \mathrm{~km}$ wide, consisting of the Akwapimian quartzites, slates, phyllites and sandstones, bounded by the Pan African Front (PAF) tectonic fault (referred to as the Akwapim Fault or Accra West Boundary Fault) to the west or northwest, and the Pan African Suture (referred to as the Accra East Boundary Fault or Coastal Boundary Fault) to the east. The adjoining external unit to the east is the main Dahomeyide block. This Dahomeyide block has high pressure metamorphic rock assemblages of mafic and felsic gneisses and deformed granitoids and schists, along with ultramafic and mafic intrusions, ophiolitic members and suture-zone melanges, all traceable along the suture zone, generally striking northeast and dipping to the southeast from the Atlantic coast inland. The Accra City (Accra Central) itself is located partly on the internal Akwapimian block and underlain in part by Akwapimian rocks, and partly in the south by Devonian to Cretaceous basinal marine sedimentary sequence known as the Accraian formation. The Accraian formation is fossiliferous and consists of successions of alternating members of sandstone, shale and mudstone with associated thin ironstone layers, and grit at the base, which sequence overlies the Dahomeyide basement of thrust sheets and fold belts [2, 11, 12, 13, 14]. The Accraian Basin is tectonically closed in convergence tectonics from east to west and accreted to the eastern margin of the Akwapimian Range and rocks. Both Accraian and Akwapimian units are sandwiched in the boundary between the crustal blocks of the Dahomeyide Orogen and the Birimian lithotectonic unit. The Birimian rocks in Ghana consist of deformed and metamorphosed volcanites and sedimentary rocks, and intrusive Eburnean granitoids [2, 12, and 14]. NESW trending faults are marked by the East and West Accra region boundary faults and by lines of crushed and fragmented blocks through the Accraian sequence subjected to compressive and transpressive tectonic strike-slip shear deformation.

Offshore in the Gulf of Guinea, three main NE-SW-trending east-dipping transpressional structures and fracture zone faults are recognized that reach onshore from the Mid-Atlantic and the Romanche Transform and Fracture Zone [15, 10]. The Romanche fracture zone fault occurs at the eastern end of the Romanche Transform fault zone. The main 
eastern extension of the Romanche fracture zone fault terminates onshore near Goi-Sege some $70 \mathrm{~km}$ east of Accra and links the on-land Fenyi-Yokoe fault and Trans-Saharan Mobile Belt shear system [10]. Internal splays of the Romanche fracture zone and other fracture zone fault systems come onshore west of Accra as the Accra Coastal boundary fault and into the Akwapim boundary fault.

Up till now it has not been clear what was causing the seismicity of the region. And the questions are asked: is the Dahomeyide mobile belt still active and causing crustal movement? Is the Romanche fracture zone system receiving and adjusting to stresses from the Mid-Atlantic Ridge and sea-floor spreading?

\section{Methods}

The approach used was to reassess historical earthquake data of southern Ghana and re-interpret the 1939 Accra Earthquake with new field data. Seismic data obtained from historical earthquake records and published works on the southern Ghana seismic zone, including those of the Ghana Geological Survey [2, 3, 5, 6, and 9] are reviewed and reinterpreted based on new tectonic and structural data and information on the local and regional geology of the Accraian, Dahomeyide and Birimian terranes gathered from the field. Historical earthquake dates were correlated to deduce any patterns of seismic cyclicity. Field work results on the geology and tectonics were used with existing 1939 Earthquakes parameters in finding and constraining causes of the seismicity of the region.

\section{Results}

The results of the geological phenomenon assessments and measurements made soon after the 1939 Accra earthquake and those made over the years of the characteristics and parameters of it are presented in Table 1. The findings show that the 1939 earthquake struck the Accra region on 22nd June 1939, at about 7:20 pm (GMT) local time [2]. It lasted and was felt for a 'bracketed' period of 20-30 seconds. It was a large, normal tectonic earthquake accompanied by foreand after-shocks. It was reported as a single shock that increased gradually to a peak and then died away. Other accounts therein had it that the earthquake occurred in two stages with a brief time interval between the earlier stage and a second more intense stage.

\begin{tabular}{|c|c|c|}
\hline \# & Earthquake Characteristic & Description/ Value /Meaning \\
\hline 1. & Genetic Type & Tectonic. \\
\hline 2. & Intensity (Maximum) & IX - X (Modified Mercalli scale, 1998 EMS, etc.). [1, 2] \\
\hline 3. & Duration & $20-30$ seconds $[1,2]$ \\
\hline 4. & Epicentral Location & $\begin{array}{l}40 \mathrm{~km}\left(25 \text { miles) offshore, SE of Accra at approx. } 5^{\circ} 11^{\prime} \mathrm{N}, 0^{\circ} 8^{\prime} \mathrm{W} \text {, in the }\right. \\
\text { Gulf of Guinea [2]. }\end{array}$ \\
\hline 5. & Depth of Focus & 8 miles depth [2]. \\
\hline 6. & Magnitude (M) & 6.5 (Richter scale) [2]. \\
\hline 8. & Foreshocks & $\begin{array}{l}\text { Yes, present and quite high number; some felt a few days, hours, and } \\
\text { minutes before the event [2]. }\end{array}$ \\
\hline 9. & Aftershocks & $\begin{array}{l}\text { Yes, present and quite high number; some felt several months after the event } \\
\text { [2]. }\end{array}$ \\
\hline 10. & Areal Coverage & Medium size area, $300,000-600,000$ sq. miles $[1]$ \\
\hline \multirow[t]{2}{*}{11.} & Fissure trends & $030^{\circ}\left(\mathrm{N} 30^{\circ} \mathrm{E}\right)$ for over $3 \mathrm{~km} \mathrm{[2].}$ \\
\hline & Fault Plane Attitudes & Strike $009^{\circ}$, subvertical $80^{\circ}$ dip (E or W) [3]. \\
\hline 12. & Strong Ground Motion & $\begin{array}{l}\text { Fast fault-rupture type, fast seismic waves; peak ground velocities } 9.2-37.1 \\
\mathrm{~cm} \mathrm{~s}^{-1} \text {; peak ground acceleration } 0.14-0.57 \mathrm{~g} \text { (i.e. } 1.373-5.590 \mathrm{~ms}^{-2} \text {, for } \mathrm{g} \\
=9.80665 \mathrm{~ms}^{-2} \text { Standard) }\end{array}$ \\
\hline 13 & $\begin{array}{l}\text { Inversion final models: Strike, Dip, } \\
\text { Rake, Moment for (Event } 1 \text {; Event } \\
\text { 2) respectively }\end{array}$ & $\begin{array}{l}\text { Strike }\left(350^{\circ}, 061^{\circ}\right), \operatorname{Dip}\left(86.2^{\circ}, 88.2^{\circ}\right), \text { Rake }\left(3.1^{\circ}, 4.9^{\circ}\right) ; \text { Moment } \\
\left(1.7 \times 10^{25} ; 4.2 \times 10^{25} \text { dyn cm }\right)[16] .\end{array}$ \\
\hline
\end{tabular}

The position of the epicentre was located offshore, some $40 \mathrm{~km}$ in the Gulf of Guinea, south of Accra, having coordinates of $5^{\circ} 11^{\prime} \mathrm{N}, 0^{\circ} 8^{\prime} \mathrm{W}$. The focal origin (hypocentre) was determined to be $13.4 \mathrm{~km}$ depth, making it a shallow earthquake $\left[17,18\right.$, and 19]. The felt-area coverage was estimated at 300,000 square miles (i.e. $7.8 \times 10^{5} \mathrm{Km}^{2}$ ) of inhabited land, and probably larger area of at least 600,000 square miles $\left(15.60 \times 10^{5} \mathrm{~km}^{2}\right)$, including uninhabited areas both on-land and offshore [1]. The areal coverage was medium, and the causative fault was a high-angle strikeslip NNE-trending fault. Maximum assigned intensity was between IX-X and the magnitude was 6.5. The intensity of 
the quake at the epicentre could not be determined, it being offshore. The assigned maximum intensity on the Modified Mercalli scale however reached a high intensity of IX onshore along the coast between Accra Central and Fete to the west (Fig. 1). Clearly, the epicentral intensity was deemed to be higher, most probably X [1]. Hence, the assigned maximum intensity of the 1939 Accra Earthquake was between IX-X. The core area shaken, according to Junner et al. [2], at isoseismal intensity IX included Nyanyanor, Fete, Aplaku, Amanfro, Tokuse, Tetegbu, Sakumo Lagoon; those of intensity VIII covered James Town (coastal part of Accra Central), and Accra west suburbs including Weija, Oblogo, Bortianor, Kokrobite, Oshia (Oshien), and places further west at Nakwa near Saltpond, then northeast Accra at Tesano; while intensity VII affected other parts of Accra such as Oduponkpehe, Achimota, Ofankor, Avenor, Alajo, Kokomlemle, Adabraka, East Ridge, Cantonments, Labadi, Korle Gonno, and Korle Bu. The Accra coastal areas and communities were most affected by the earthquake hazard and suffered the most disaster. Casualty counts showed that 17 people lost their life and 135 people got injured at the coastal James Town suburb of Accra. Settlement buildings collapsed along the coasts at Nyanyanor, Kokrobite, Bortianor, Oblogo and other places. The assessments of Junner et al. [1] also showed that the principal direction of material failure, fall and collapse of objects and walls were northwest (NW) and southeast (SE) at Accra Central, Weija, Oblogo, Aplaku, Bortianor, Kokrobite, Oshia, Damba, and Nyanyanor (Fig. 2)
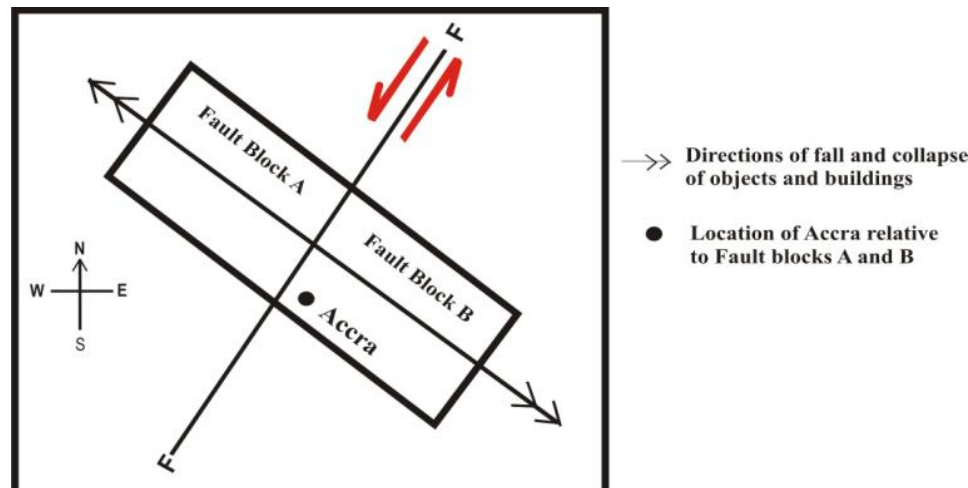

- Location of Accra relative to Fault blocks $A$ and $B$

Fig. 2: Model diagram showing the direction of fall and collapse of objects on the Accra region (block $\mathbf{B}$ ), and the Akwapimian fault (sinistral shear) relative to the Birimian block $\mathbf{A}$

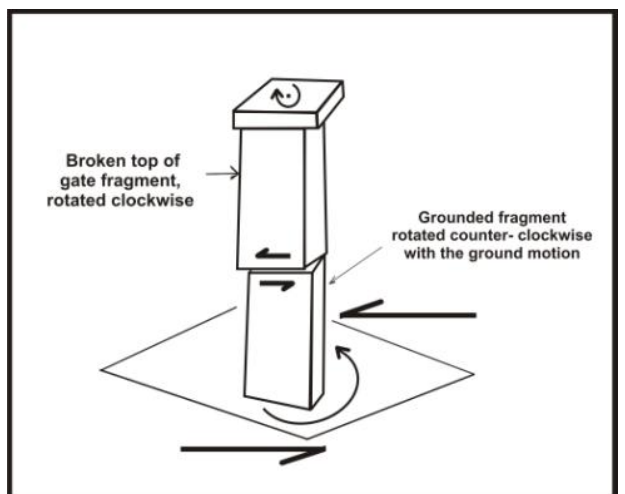

Fig. 3: Showing sinistral torsional deformation (redrawn Fig. 2 of plate VI of Junner et al. [2]).

At Nyanyanor, Weija, and Accra Central, several buildings and structures collapsed to the NW or SE; and a few concrete gates got fractured and sheared in Accra, such that their upper sections got broken, shifted and rotated over the grounded piece about $10^{\circ}$ in the clockwise sense (Fig. 3; after Junner et al., Plate VI, Fig. 2 [2]), indicating sinistral (counterclockwise) sense shear faulting and fault block motion. Liquefaction occurred at Sakumo lagoon area, and lines of earthquake fissures opened at Sakumo lagoon, Korle lagoon, Accra Central, Tesano, and between Weija and Fete. Spectacular "en echelon" fissures trending N $30^{\circ} \mathrm{E}\left(030^{\circ}\right)$ and stepped-down towards southeast occurred for over $3 \mathrm{~km}$ from Kokrobite to Oduponkpehe in alluvium between Weija and Fete, closer to the Akwapimian scarp or AkwapimianBirimian boundary [2]. The trend of fissures from Kokrobite through Oduponkpehe to Weija (Fig. 4) seem to reflect the direction of propagation of the dominant seismic waves from SE to NW radiating along fault splays and away from the strike of the causative fault plane which would be NE-SW. 


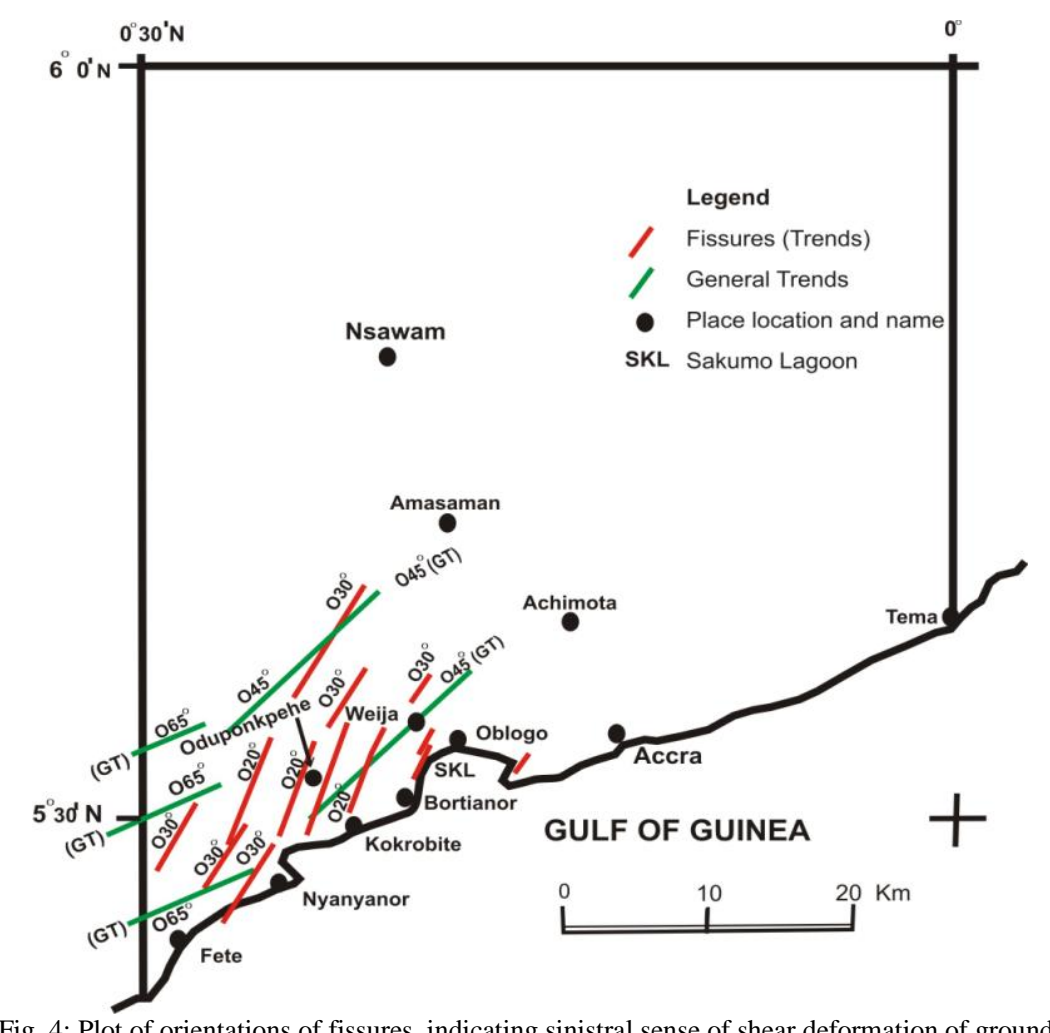

Maximum ground acceleration and velocity were not obtained for the event at the time. The maximum ground acceleration could be determined by using instrumental records of ground motion, or use of accelerograms of earthquakes of comparable source, path and geological characteristics to the 1939 Accra Earthquake, available in databases, which can be collectively analysed to derive acceptable mean parameters for the region. But both instrumental data and data-base resources are unavailable. Amponsah et al. [9] used theoretical methods to simulate the maximum ground velocity and acceleration for the 1939 Accra event and obtained peak ground velocity and acceleration to be 9.2 $-37.1 \mathrm{~cm} \mathrm{~s}^{-1}$ and $0.14-0.57 \mathrm{~g}$ respectively (Table 1 ). Full understanding of the seismic parameters and wave properties are useful in physical terms that include insight on influence of destructive forces and their directions of impact on structures, people and the environment. Direction of fall and collapse of structures in the 1939 event was SE and NW, indicating direction of maximum ground velocity and acceleration. The earthquake was a heavily damped in the Accra region, making it more destructive locally.

The results of the present re-evaluation of the characteristics and parameters of the 1939 Accra earthquake are presented in Table 2 and discussed in the rest of the section.

The results of the re-interpretation indicate that the 1939 earthquake was caused by a shallow-depth northeast trending fault that propagated heavily along the Accra boundary faults.

Mapping results of affected parts of the Accra seismic area showed the general foliation of the Akwapimian rocks fall within a strike range of $020-060^{\circ}$ and dip range of $16-55^{\circ} \mathrm{E}$, as in quartzites, phyllites and sandstones at Weija $\left(042^{\circ} / 36^{\circ}\right.$ E), Aplaku $\left(070^{\circ} / 40^{\circ} \mathrm{E}\right)$, Accra Central -Kinbu $\left(060^{\circ} / 6^{\circ} \mathrm{E}\right)$, Tesano $\left(050^{\circ} / 46^{\circ} \mathrm{E}\right)$, Alajo $\left(038^{\circ} / 54^{\circ} \mathrm{E}\right)$, Dzorwulu $\left(040^{\circ} / 54^{\circ} \mathrm{E}\right)$, Achimota $\left(046^{\circ} / 16^{\circ} \mathrm{E}\right)$. The results of the field work showed that the general bedding foliation of the rocks at Kokrobite-Bortianor was $050^{\circ} / 24^{\circ}$ E. This mean foliation had been cross cut by two faults: an earlier fault $\left(\mathrm{F}_{1}\right)$ of attitudes $280^{\circ} / 90^{\circ}$ that change gradually to $090-076^{\circ} / 90-85^{\circ} \mathrm{E}$, and a later fault $\left(\mathrm{F}_{2}\right)$ of attitude $060^{\circ} / 80^{\circ} \mathrm{E}$ that also swings to $050^{\circ} / 90-85^{\circ} \mathrm{E} / \mathrm{W}$. The $\mathrm{F}_{1}$ fault is the extension of the Ivory Coast Fault into Ghana, while $\mathrm{F}_{2}$ is the Accra Coastal boundary Fault (Figs. 5, 6, \& 7). The cross faults are sinistral shear faults bounding the Accra region between the Birimian and Dahomeyide terranes (Figs. 8 \& 9).

These results provide ground evidence that the 1939 Accra Earthquake was a normal shallow-focus tectonic reactivated northeast trending strike slip-fault earthquake. Quaah [3] gave a fault strike of $009^{\circ}$ on a dip of $80^{\circ}$. Junner et al. [2] gave the trend of the actual "en echelon" fissures on the ground between Weija and Fete as $\mathrm{N} 30^{\circ} \mathrm{E}\left(030^{\circ}\right)$ within a general structural direction that swung between northeast swinging between $045^{\circ}$ and $060^{\circ}$, as shown in Fig. 4 . That indicates a sinistral subvertical shear deformation within the Accra-Fete-Weija triangle of the Akwapimian block of the Accra region. 
Table 2: New Reinterpretation of the 1939 Accra Earthquake

\begin{tabular}{|c|c|c|}
\hline \# & $\begin{array}{l}\text { Earthquake } \\
\text { Characteristic }\end{array}$ & Description/ Value /Meaning \\
\hline 1. & Genetic Type & Tectonic, old, shallow-focus, transcurrent reactivated fault earthquake. \\
\hline \multirow[t]{6}{*}{2.} & Intensity (Maximum) & Same as in Table 1, onshore. \\
\hline & Duration & Same as in Table 1, shallow-focus earthquake. \\
\hline & Depth of Focus & $13.4 \mathrm{~km}$ (8 miles) depth, i.e. shallow-focus earthquake $(<70 \mathrm{~km})$. \\
\hline & (Hypocentre) & Same as in Table 1 , shallow-focus earthquake. \\
\hline & Foreshocks & Same as in Table 1, shallow-focus earthquake. \\
\hline & Aftershocks & \\
\hline 3. & Magnitude (M) & $6.5+(\sim 7$. Richter scale $)$, Large earthquakes $(5.5<\mathrm{M}>8.0)$. \\
\hline \multirow[t]{3}{*}{4.} & Fault Plane Attitudes & $\mathrm{F}_{1}: 280^{\circ} / 90^{\circ}$ and $\mathrm{F}_{2}: 060^{\circ} / 80^{\circ}$ East (at Kokrobite) \\
\hline & Fissure trends & $020^{\circ}-030^{\circ}$ \\
\hline & Romanche Fault & $060^{\circ}$ (eastern extension towards Ghana coast) \\
\hline 5. & Fault Plane Length & $\begin{array}{l}\text { Apparently small - medium, within } 30-60 \mathrm{~km}(<100 \mathrm{~km}) \text {, vertical strike-slip, based on } \\
\text { limited splay or offshore distance from Accra coast }(<100 \mathrm{~km}) \text {. }\end{array}$ \\
\hline 6. & $\begin{array}{l}\text { Finite Fault Slip \& Slab } \\
\text { Width }\end{array}$ & $\begin{array}{l}\text { Fast slip of cold brittle tectonic layer at high crustal level; Small - medium displacement } \\
\text { on order of } 1-2 \mathrm{~m} \text { vertical ; Slab width of } 40 \mathrm{~km} \times 2 \text { sides of hypocentre, equivalent to } 80 \\
\mathrm{~km} \text {, based on average brittle confined continental crustal faulting. }\end{array}$ \\
\hline 8. & Periodicity & Normally random, non-cyclic, based on old reactivated fault movement. \\
\hline
\end{tabular}

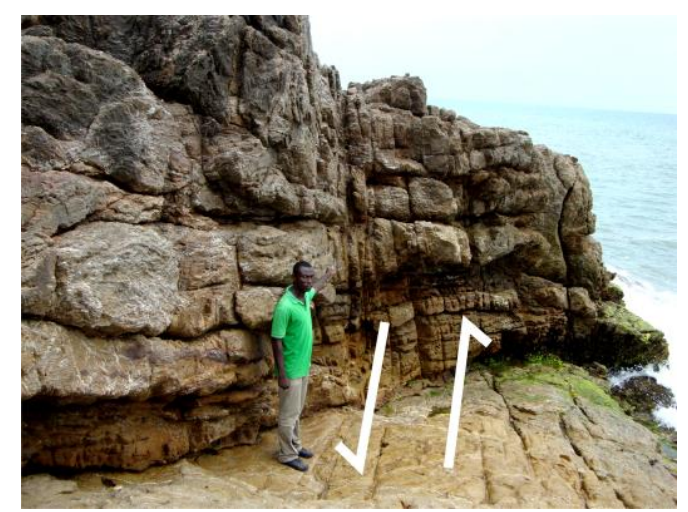

Fig. 5: Showing the subveritical strike-slip Akwapimian fault trace $\left(\mathrm{F}_{1}\right)$ at Kokrobite (Accra west), in Akwapimian quartzite; trending south offshore in the Gulf of Guinea.

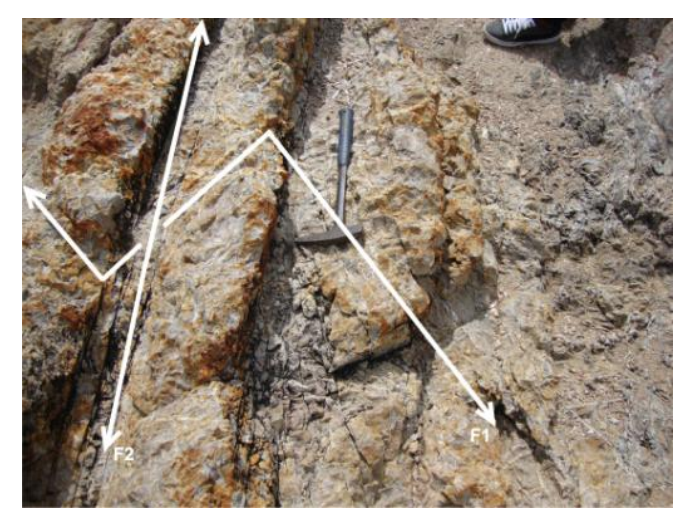

Fig. 6: Showing the two faults subvertically crossed at Kokrobite beach (Accra west), in brecciated quartzite, of subveritical strike-slip Accra coastal boundary fault $\left(\mathrm{F}_{2}\right.$ : hammer trend, bottom-left to top-right) and the older Akwapimain boundary fault ( $\mathrm{F}_{1}$ : kinked, trending bottom-right to top-left). 


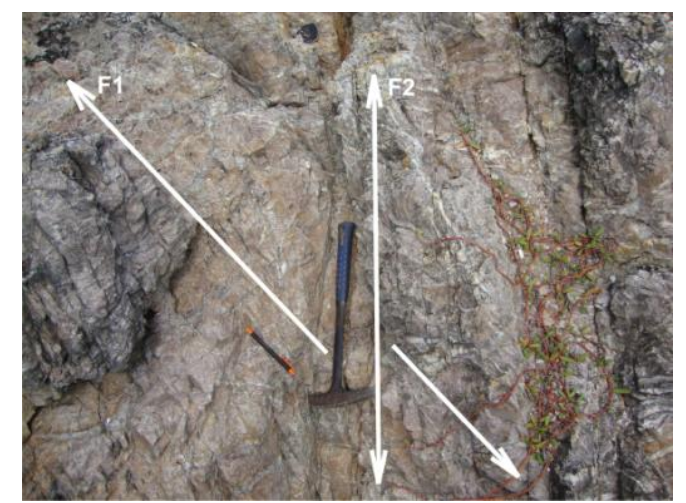

Fig. 7: Showing the cross faults at Kokrobite (Accra west), in Akwapimian quartzite, of subveritical strike-slip Accra coastal boundary fault ( $\mathrm{F}_{2}$ : hammer trend) and the older Akwapimain boundary fault (pen trend).

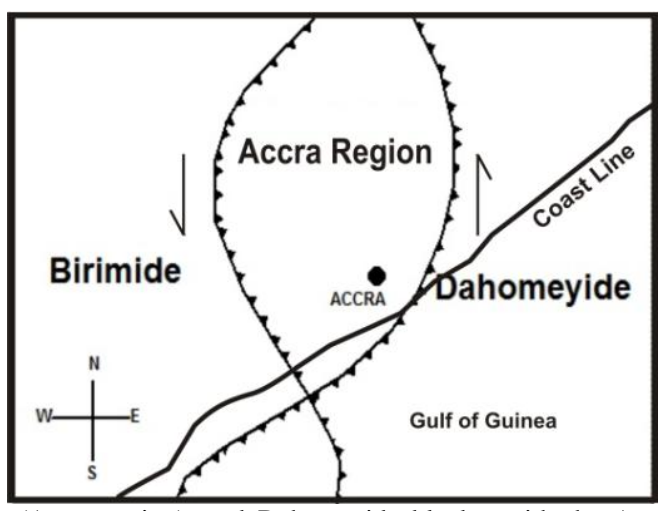

Fig. 8: Showing the Birimian, Akwapimian (Accra region), and Dahomeyide blocks: with the Accra region block (passive) sinistrally sheared between the Birimian and Dahomeyide tectonic blocks.

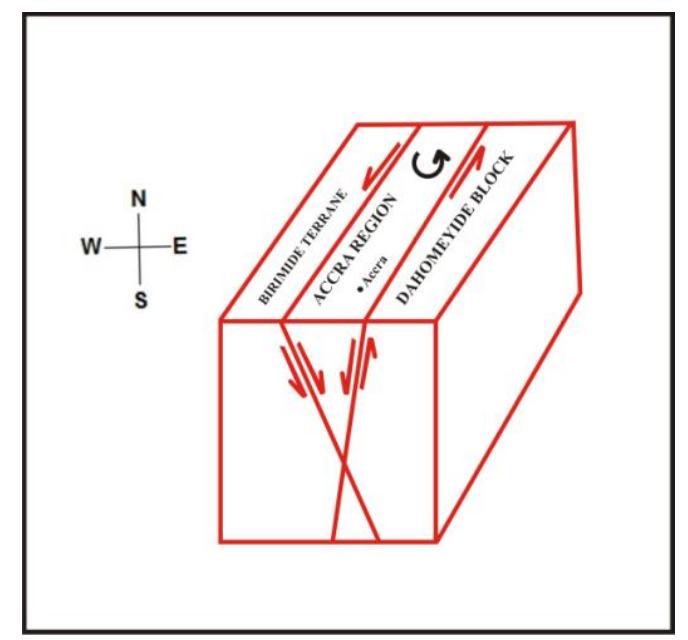

Fig. 9: Showing the 3-D block diagram of the Akwapimian Accra region block (passive and subsided) between the Birimian and Dahomeyide tectonic blocks that was sinistrally sheared and thrown downthrown towards the east in the 1939 earthquake.

It is apparent that the seismic fault plane was subjected to shear forces leading to ground failure in a subvertical transcurrent or transpressional strike-slip fault; a process related to tectonic activity involving fault splays of the Romanche Fracture Zone [15, 10]. These splays are represented by Accra boundary faults. The Accra-block boundary faults intersect as cross-faults southwest of Accra at Kokrobite (Figs. 6 \& 7), apparently winding as interfering transcurrent faults in sinistral sense (Figs. 8 \& 9). This indicates tectonic shear disruption of the crust into three faultparallel subvertical blocks, with apparent detachment of the middle block - the Accra region block. This fault system has been linked to several historical earthquakes in the region [5]. Accra is located on the middle Akwapimian block, which constitutes the Accra region or seismic block. Such a block, if fully detached becomes passive, and will become subjected to tectonic stabilization adjustment and much seismic damping. This fault system appears to be one of the sources of the recent seismicity of the region. Displacement of a ruptured slab length on the fault plane may generate mechanical or seismic waves propagated through the block. Even though the finite the displacement of the 1939 Accra 
Earthquake remains unknown, it can only be of the order of 1.0 to 2.0 metres drop, as this quake was essentially due to strike-slip faulting.

Time correlation of major historical earthquakes to determine patterns of seismicity, notably those of 1862, 1906, and 1939, are shown in Table 3. The time gap between the 1862 and 1939 events gives an interval of 77 years between the two events (Table 3). Both events had been assigned maximum seismic intensity IX and magnitude 6.5 [2]. And the interval between 1939 and present year 2013 is 74 years. The occurrence of major earthquakes this far from existing data does not indicate periodic seismicity in southern Ghana.

Table 3: Historical data and time intervals of major earthquakes in Ghana

\begin{tabular}{cccccccccc}
\multicolumn{10}{c}{ Table 3: Historical data and time intervals of major earthquakes in Ghana } \\
\hline Year & 1615 & 1636 & 1862 & 1872 & 1906 & 1939 & 1969 & 1997 & $2013 ?$ \\
\hline Intensity & - & IX & IX & VII & VIII & IX & - & - & $?$ \\
Magnitude & - & $5.7\left(\mathrm{M}_{\mathrm{S}}\right)$ & $6.5\left(\mathrm{M}_{\mathrm{L}}\right)$ & 4.9 & $6.2\left(\mathrm{M}_{\mathrm{L}}\right)$ & $6.5($ Richter $)$ & 4.7 & $4.8($ Richter $)$ & $?$ \\
Location & Elmina & Axim-Abidjan & Accra & Accra & Ho & Accra & Accra & Accra & $?$ \\
Cycle Interval & - & 21 & 247 & 10 & 34 & 33 & 30 & 28 & $44 ?$ \\
\hline
\end{tabular}

(Data sources: Nature 147 [1]; Junner et al. [2]; Quaah [3]; Amponsah [5, 6])

\section{Discussion}

Earthquakes are natural crustal rupture and stabilization phenomena that help maintain the spheroidal structure of the Earth, so the global phenomenon will continue until the Earth loses all of its internal tectonic energy. Earthquakes are classified based on the depth of focus as (i) shallow-focus or normal earthquake, that occurs at a depth less than $\sim 70$ $\mathrm{km}$, (ii) intermediate-focus earthquake that occurs between $\sim 70$ and $300 \mathrm{~km}$, and (iii) deep-focus earthquake that occurs at depth 300 to $700 \mathrm{~km}[17,18,19]$. The number of aftershocks is a fair measure and indicator of the depth and thermal state of the faulted rock layers or slabs and deep-earthquakes show few or no aftershock productivity [20]. The smaller the number of aftershocks, the hotter more plastic and deeper the slab is; while the larger the number of aftershocks, the colder, more elastic and shallower the slab is. The 1939 Accra Earthquake came associated with several significant foreshocks and aftershocks [2]; that indicates shallow depth earthquake. The seismicity of southern Ghana can only emanate from shallow depths $(<20 \mathrm{~km})$ of cold brittle crust. The 1939 earthquake was characterized by high foreshock and aftershock productivity, indicative of shallow-focus, brittle, elastic, cold, high-strain slab faulted over quite moderate length and slab thickness or width, accounting for a moderate size area and moment.

The maximum intensity of the 1939 earthquake was estimated onshore to be between IX - X (Table 3). The intensity varied much in Accra Central from VII to IX [2] and along the coastal areas. This variation of the effects on infrastructure, people and environment was due to local variations in the underlying basement geology and distance from the source and boundary faults, the distribution of quaternary sediments, soil and alluvium. The earthquake was therefore heavily damped and quickly by the fractured Accraian faulted rocks and the Akwapimian block itself, local variations in the underlying basement geology and faults, in addition to the quaternary sediments and ocean water.

Open en echelon fissures developed in the ground trending $020^{\circ}$ to $030^{\circ}$ and stepped down towards southeast. They occurred alongside shear structures [2]. Together, their configurations indicate a sinistral sense of shear movement of the ground and a drop of the Akwapimian block (Figs. 8,9). This sense of movement was further supported by broken gate pillars of concrete buildings rotated sinistrally (Junner et al., 1941, Plate VI, Fig. 2 [2]). This agrees with the sinistral rotation of Yarwood and Doser [16].

The magnitude was estimated at the magnitude 6.5 , but it apparently was higher, as it originated as a submarine quake some 40 kilometres offshore, where the magnitude could well be 7.0 on the Richter scale. Major earthquakes of magnitudes greater than 7.0 are rare onshore in Ghana, and seismic data are limited.

Seismicity based on earthquake cycle intervals is unknown in Ghana; if even a cycle exists the pattern is not evident. The statistics in Table 3 does not give a clear pattern of occurrence. The emerging patterns are based on the 77 years interval (1862- 1939 Accra cycle?) or 74 years interval (1939-2013 Accra cycle?). The 77 years interval is intersected by the 1862-1906 time gap (34 year-cycle) and 1906-1939 gap (33 year-cycle) as shown in Table 3. In southern Ghana, including Accra region, there are no known major earthquake sequences, and no clustered concentration of earthquakes have occurred at the end of the 74-year presumed seismic cycle. It is seismic gaps in tectonic plate faulting that tend to rupture cyclically. According to Thatcher [21] earthquakes that tend to recur regularly do rupture periodically along seismic gaps and concentrate strain periodically towards the end of a seismic cycle and recur with increasing size and magnitude. Absence of any known rupturing seismic gaps in southern Ghana would appear to negate argument for the probability of crustal slabs accommodating stress and accumulating strain to rupture in a recurrent major earthquake at any moment in the region. The aftershocks have long died down after the 1939 Accra event, and there are no significant foreshocks being experienced today. Historical seismic records do not indicate that the major events in Ghana had occurred in seismic gaps in the last 400 years. Time correlation of historical events and patterns of seismicity do not 
shown existence of any periodic pattern. Indeed, forecasting of earthquake itself is difficult, and forecasting for the Accra region based on seismic cyclicity even is harder to support. Our question is: Does southern Ghana, encompassing the Accra region, have or qualify to have seismic cyclicity at all? Does the region have rupturing segments of rock layers or slabs propagating segment-by-segment through time with some waiting un-ruptured gaps, referred to as seismic gaps. We think Ghana does not have. The seismicity of southern Ghana does not seem to be recurrent, but rather an indication of a more irregular or random complex on-going activity. This activity seems to deviate from the normal type; it is marked by non-periodic seismicity, including microseismic activity, as such poses problems for general prediction and recurrence.

The Accra region, located at the West African passive continental margin, is related to the eastern end of the Romanche Transform Fault (RTF) offset some 888 kilometres long from the diverging Mid-Atlantic ridge [22, 10]. Extending eastward from the Romanche Transform Fault (RTF) is the 1890-kilometre long Romanche Fracture Zone, which probably is interacting with adjacent fracture zones. This appears to be the source of the seismicity. The region must be experiencing fault movements associated with the Romanche transform fault and fracture zone system and related nearby St Paul and Chain fracture systems. The epicentre of the 1939 Accra Earthquake was located $40 \mathrm{~km}$ south of Accra, with its focus at $13.4 \mathrm{~km}$ depth, making it a shallow-focus earthquake probably located on the continental shelf segment of Romanche fracture zone fault. Transform faults commonly generate large shallow-focus earthquakes at depth between 10 to 20 kilometres [23, 24]. Also transform and fracture zone boundaries tend to be zones of linked faults and splays, be they single or bands of planes of strike-slip movements [25], which interact with each other in constant shear, compressional and extensional stresses [25] to adjust and achieve crustal stability.

In the early assessments, some account had it that the earthquake occurred in two stages with a brief time interval between the earlier stage and a second more intense stage [2]. That could well be so, either due to the interval between arrival times of $\mathrm{P}$ - and $\mathrm{S}$-waves respectively, or the effect of two coincident events, one triggering the other. Yarwood and Doser [16] have it that there were two close events. In that case the first could have triggered the second. Such occurrences could happen where cross faults and detached passive blocks exist as in the Accra region.

One reason why it is difficult to predict earthquake in the Accra region is that the region is a low seismicity zone and the causes are not well understood. It is without clear trends in the seismic activity. Also, the remote cause of the earthquakes is quite far from southern Ghana, in the Mid-Atlantic ridge. The faults responsible for the earthquakes may be old ancient faults (Proterozoic or Pan African age or at least 65Ma old formed during the opening of the south Atlantic), that are only being reactivated by present-day tectonic movements. Historical record of earthquakes in the region is low. The general absence of detailed earthquake data in the offshore environment of Ghana constrains necessary work to identify the potential earthquakes causes and sources.

However, one interesting geological and useful indicator preceded the 1939 Accra Earthquake event: there were precursors cracks in Accra, reported in Nature 147 [1], as "Between 1932 and 1935 cracks began to appear in substantial government buildings and on the grounds near them, ... and Dr. N.R. Junner, then Director of the Geological Survey of the Gold Coast (now Ghana) directed public attention to the possibility of occurrence of earthquakes during the next 10 - 15 years"; and it occurred in 1939, five years later. Also the earthquake was preceded by foreshocks, all indicative of imminence of occurrence of significant earthquake in the region. No such precursors are recognized today, except weak diminishing microseismic activities.

\section{Conclusion}

Conclusions are presented on the results of the re-interpretation of the 1939 Accra tremor, the nature and causes of the seismicity of the region, and likelihood of recurrence of major cyclic earthquake in the region.

The 1939 Accra earthquake was moderate or large size, shallow-focus tectonic event that ruptured 40 kilometres offshore south of Accra. The causative fault was a high-angle sinistral strike-slip submarine fault. The assigned onshore magnitude of 6.5 and maximum onshore intensity of IX-X in the Accra region are most probably lower than the actual offshore magnitude which may likely have reached magnitude 7 (Richter scale). The earthquake was heavily damped both offshore and onshore.

The Accra Coastal Fault and Akwapim Fault form a cross-fault at Kokrobite west of Accra. These faults are fault splays linked to and in interactions with the Romanche and adjacent fracture zones; and their movements are related to the causes of 1939 Accra Earthquake and recent seismicity of the region. The current seismicity of the region future appears to emanate from complex system of transform-fracture zone movements and small crustal stabilization adjustments of the Accra region block locked between the adjoining Birimian and Dahomeyide blocks.

Seismicity in the region is not cyclic, but normal non-periodic events due to interactions and movements of the Romanche and nearby fracture zones. Seismicity based on earthquake cycle intervals is unknown for Ghana. The reasons the expected recurrence of a major earthquake has not happened after the 1939 tremor, in 74 years, is because seismicity in southern Ghana is not cyclic, but rather irregular kind and related to remote causes associated with the 
Mid-Atlantic Ridge and the Romanche Transform fault and fracture zone. The seismicity pattern and characteristics of southern Ghana and Accra region show that the region is a relatively low seismicity region.

However, the conclusions do not preclude the possibility of occurrence of any significant earthquake trembling Accra region or southern Ghana now or in future. Clearly, the earthquake activity in southern Ghana has not ended, but will continue in response to crustal adjustments, as there are many independent faults associated with the still active transform and fracture systems offshore.

\section{Acknowledgements}

Funds and support for this research came from the University of Ghana "Book \& Research Allowance Facility" and Geodita Consult. Thanks to the Ghana Geological Survey for using the bulk of the historical earthquake data.

\section{References}

[1] Nature 147, The Accra Earthquake of June 22, 1939; NATURE; available online: http://www.nature.com/nature/journal/v147/n3737/abs/147751a0.html; 14 June 1941; accessed 5 June 2013.

[2] N.R. Junner, D.A. Bates, E. Tillotson, C.S. Deakin, The Accra Earthquake of 22nd June, 1939; Gold Coast Geological Survey Bulletin No. 13 (1941) $1-57$

[3] A.O. Quaah, Microseismicity, Past Seismic Activity and Seismic Risk in Southern Ghana; PhD Thesis, University of London; (1980) 223 pp.

[4] N. N. Ambraseys and R.D. Adams, Seismicity of West Africa; Ann. Geophysicae., 4B (6) (1986) $769-702$.

[5] P.E. Amponsah, Seismic activity in relation to fault systems in southern Ghana; Journal of African Earth Sciences 35 (2002) 227 - 234.

[6] P.E. Amponsah, Seismic activity in Ghana: past, present and future; Annals of Geophysics, vol. 47, No. 2/3 (2004) 539 - 543.

[7] Ghana News Agency, Earthquake: Accra on time bomb, ModernGhana, available online: http://www.modernghana.com/news/8211/1/earthquake-accra-on-time-bomb. Html, 4 January 2000 , accessed 5 June 2013.

[8] Ghana News Agency, Accra on the verge of another earthquake - GSD, ModernGhana, available online http://www.modernghana,com/news/60242/1/accra-on-the-verge-of-another-earthquake-GSD. Html, 3 August 2004 , accessed 5 June 2013.

[9] P.E. Amponsah, B.K. Banoeng-Yakubo, F. Vaccari, D. Asiedu, G. F. Panza, Seismic ground motion and hazard assessment of the Greater Accra Metropolitan Area, southeastern Ghana; The Abdus Salam Int. Centre for Theoretical Physics, IC/2008/055, Miramare-Trieste; (2008) $1-19$.

[10] K. Attoh, L. Brown,; J. Guo, J. Heanlean, Seismic stratigraphic record of transpression and uplift on the Romanche transform margin, offshore Ghana; Tectonophysics 378 (2004) $1-16$.

[11] A.E. Kitson and A.M. Davies, Devonian rocks of Accra; 13th Int. Geol. Congr. Report, Part 2, (1922) $945-947$.

[12] W.J. McCallien, The rocks of Accra; University of Ghana Publ. Board, Legon - Accra, (1962).

[13] W.R. Fitches, "Pan African Orogeny" in the coastal regions of Ghana; NATURE vol. 226, no. 5247 (1970) 744 - 748.

[14] G.O. Kesse, the Mineral and Rock Resources of Ghana; A.A.Balkema Publishers, the Netherlands - Rotterdam, Boston, (1985).

[15] D.J. Blundell and J.K.A. Banson, Interpretation of seismic reflection survey across the continental shelf south of Accra and its bearing on Earthquakes in the area; Ghana Geological Surv. Report No. 75/1; (1975).

[16] D.R. Yarwood and D.I. Doser, 1990, Deflection of oceanic transform motion at a continental margin as deduced from waveform inversion of the 1939 Accra, Ghana earthquake, Tectonophysics 172 (1990) 341 - 349

[17] M. Gary, R. McAfee Jr, C.L. Wolf (eds.), Glossary of Geology, Am. Geological Institute, Washington, D.C., (1974).

[18] B.A. Bolt, Earthquakes: A Primer; W.H. Freeman and Co., San Francisco, (1978).

[19] P. Singh, Engineering and General Geology, 8th Rev. Ed.; S. K. Kataria \& Sons, Delhi, (2008).

[20] D.A. Wiens and H.J. Gilbert, Effect of slab temperature on deep-earthquake, aftershock productivity and magnitude-frequency relations, NATURE 384 (1996.) 153-156.

[21] W. Thatcher, Earthquake recurrence and risk assessment in circum-Pacific seismic gaps, NATURE 341; (1989) 432-434.

[22] X. Le Pichon and D.E. Hayes, Marginal Offsets, Fractures Zones, and the Early Opening of the South Atlantic; Journal of Geophysical Research 76, No. 26, (1971) 6283-6293.

[23] A. Cox and R.B. Hart, Plate Tectonics: How it Works, Blackwell Scientific Publications, Inc., Palo Alto, Oxford; (1986).

[24] Kulhanek, Anatomy of Seismograms: Developments in Solid Earth Geophysics Series, 2nd Ed., Barnes \& Noble; (1990).

[25] K.M.M. Rohr, The valley that time forgot; NATURE 380 (1996) 480-481. 